Introduction: Hepatocellular carcinoma (HCC) is one of the leading causes of cancer death worldwide. There is as yet no standard therapy for inoperable HCC. We aimed to systematically review all health-related evidence regarding the effectiveness and safety of megestrol in HCC patients.

Material and methods: We conducted a systematic computerised search in PubMed, Scopus, Web of Science, Embase, and Cochrane CENTRAL. All original human studies reporting the efficacy of megestrol in HCC patients were included in our review.

Results: Six studies including $357 \mathrm{pa}-$ tients were finally eligible. The overall mean survival time of 87 megestrol-treated patients, was 9.187 (95\% Cl 1.134-17.239) months. Eight patients had tumour size enlargement, and eight patients had tumour size reduction. From three studies including 76 patients, 42 patients reported having improvement of appetite and food intake after receiving megestrol. Diverse adverse events were noticed between studies; however, they were tolerable in most of the studies.

Conclusions: To summarise, no conclusive evidence should be declared regarding the effectiveness of megestrol in patients with inoperable HCC. However, previous studies have shown promising results at the level of prolonging the survival rate, tumour size reduction, and improving the quality of life. Therefore, we recommend that future research studies must examine the role of megestrol in large-population, randomised studies.

Key words: megestrol, Megace, hepatocellular carcinoma, HCC, progestin, oestrogen receptor, hormonal therapy.

Contemp Oncol (Pozn) 2018; 22 (4): 209-214 DOI: https://doi.org/10.5114/wo.2018.82641

\section{Efficacy and safety of megestrol in the management of hepatocellular carcinoma: a systematic review of the literature}

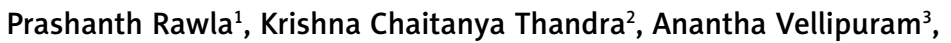 \\ Citra Dewi Mohd Ali ${ }^{4}$
}

${ }^{1}$ Department of Medicine, SOVAH Health, Martinsville, Virginia, USA

${ }^{2}$ Department of Critical Care Medicine, Memorial Sloan Kettering Cancer Centre, New York, USA

${ }^{3}$ Texas Tech University Health Sciences Centre, El Paso, USA

${ }^{4}$ Faculty of Medicine, Tanta University, Tanta, Egypt

\section{Introduction}

Hepatocellular carcinoma (HCC) is the most common of liver cancers and one of the leading causes of cancer death worldwide [1]. HCC is more common in males than females, with a ratio of $2.4: 1$. Liver cancer is predicted to be the sixth most commonly diagnosed cancer and the fourth leading cause of cancer death worldwide in 2018, with about 841,000 new cases and 782,000 deaths annually [2,3]. The incidence of HCC is high in specific regions including Middle and Western Africa and Eastern and Southern Asia, compared to lower rates in developed countries [4]. The prognosis of HCC is poor, and the five-year survival rate in the United States is less than $12 \%$. Also, the incidence of HCC has doubled in recent decades, which makes HCC responsible for a major portion of cancer-related death in the United States [5]. Different risk factors have been associated with the incidence of HCC. For instance, most liver cirrhosis patients (80\%) develop $\mathrm{HCC}$, and infection with hepatitis B virus (HBV) and hepatitis C virus (HCV) also increase the risk [6]. Patients with HCC usually experience no specific symptoms other than those of their chronic liver disorder [6]. Therefore, in the West, only $30-40 \%$ of HCC patients are diagnosed at an early stage, and they can be treated curatively through surgical resection, liver transplantation, or radiofrequency ablation when appropriately selected. In about $60-70 \%$ of those patients, the survival rate is five years, which is the prolonged survival time among all possible therapeutic modalities [7]. On the other hand, it is challenging to find a systematic therapy that can effectively manage the advanced stage of HCC, which has a grievous prognosis [8]. Currently, the European Association for the Study of Liver (EASL) and the American Association for the Study of Liver Disease (AASLD) consider sorafenib as the standard systemic remedy for patients with advanced HCC and well-preserved liver function (i.e. Child-Pugh class A) $[9,10]$. However, there are limited data about its role in patients with reduced liver function (i.e. Child-Pugh class B) [11, 12]. Oestrogen influences the growth of HCC; however, treatment with the anti-oestrogen tamoxifen demonstrated no clinical efficacy [13]. The repeated occurrence of oestrogen receptor mutations may explain the lack of tamoxifen effects [14, 15].

Megestrol is a synthetic progestin agent, with efficacious anti-oestrogen activity independent of oestrogen receptors. Zhang et al. showed that megestrol acetate inhibited the growth of human HCC (HepG2) cells grown both in vitro and in vivo. Apoptosis following $\mathrm{G}_{1}$ arrest was seen in megestrol acetate-treated cells and this may be a mechanism through which mege- 
strol acetate inhibits HepG2 cells [16]. In a single-arm trial, megestrol acetate (acylated derivative of megestrol) was beneficial in the palliative care of advanced HCC with minimal side effects, while no considerable anti-cancer effect was detected [17]. In another controlled study, the megestrol slowed down the tumour growth and significantly improved the survival rate [18]. However, another double-blinded randomised clinical trial (RCT) reported no increase in the survival time, when megestrol acetate was administered [19]. Due to the contradictory results in the current literature, we aimed to systematically review and analyse all health-related evidence regarding the efficacy and safety of megestrol in patients with HCC.

\section{Material and methods}

\section{Literature search strategy and selection criteria}

In July 2018, we carried out a systematic electronic search of five major databases: PubMed, Web of Science, Scopus, Cochrane CENTRAL, and Embase. The following search terms: (Megestrol OR Megestrol acetate OR Megace) AND (hepatocellular carcinoma OR hepatocellular cancer OR liver cancer OR liver cancers) were utilised to retrieve all potentially relevant articles. A manual search of the reference list of relevant articles was carried out to provide a comprehensive literature search. The authors independently screened the search results about the inclusion and exclusion criteria.

Our inclusion criteria comprised interventional studies, observational studies, and case reports/series that investigate the role of megestrol or its acylated form (megestrol acetate) in the treatment of patients with HCC. We excluded 1) irrelevant studies, overlapped, or unreliably extracted 2) reviews, book chapters, comments, letters, or posters, 3) studies without available full-text, 4) in vitro or animal study. The authors checked the eligibility for article inclusion via two rounds: title/abstract screening of all search results, moving to the full-text reading of potentially eligible papers.

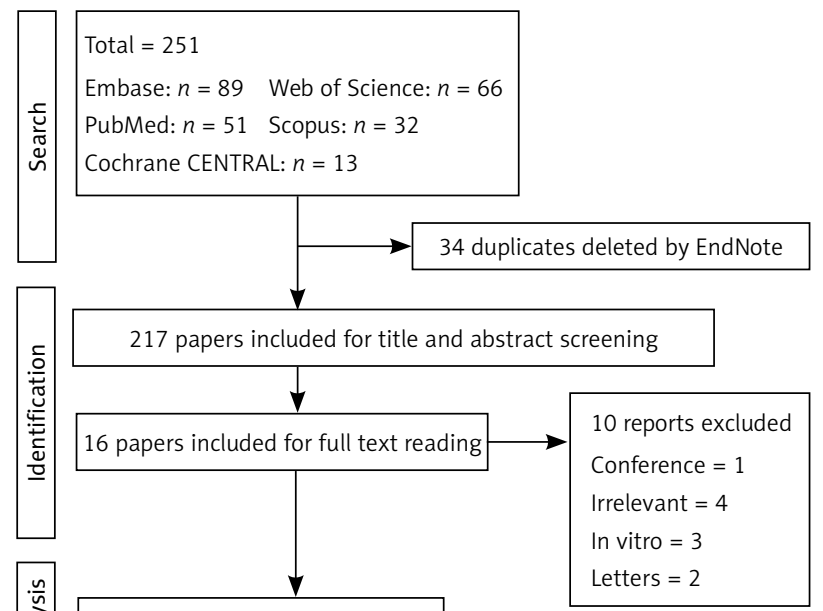

6 articles finally included

Fig. 1. Flow diagram of the studies' selection and screening

\section{Data extraction and statistical analysis}

Three independent authors performed a pilot extraction for two articles to build a standardised data extraction form. We extracted the baseline data including age, gender, country, sample size, and intervention. We also extracted the classification of data according to Child-Pugh system and/or ECOG performance score. The outcomes comprised patients' survival, tumour and AFP alterations following treatment, appetite changes, and adverse events. All data have been refined through discussion and consensus between the three reviewers. We calculated the overall mean survival with the corresponding 95\% confidence interval (Cl) using Comprehensive Meta-Analysis Software (CMA) version 3.3.070. Studies were eligible for analysis if they provide the mean and standard deviation (SD) or median and range of survival. Median and range were converted to mean and SD through the method of Hozo et al. [20].

\section{Results}

\section{Literature search}

Our systematic electronic search in five databases retrieved 251 articles. The Endnote software cleared 34 duplicated references. Upon the title and abstract screening of the remaining articles, only 16 studies were eligible for full-text reading. Eventually, six studies met our inclusion criteria [12, 17-19, 21, 22]. The flow diagram of study selection and screening is shown in Figure 1.

\section{Study characteristics}

Our six included studies consisted of three randomised, controlled trials and three non-randomised, uncontrolled clinical trials. They comprised 357 patients, and most of them were male (83.2\%). Two studies used megestrol [18, 21] while the remaining studies utilised megestrol acetate (the acylated derivative of megestrol). The administered dose of megestrol or megestrol acetate was $160 \mathrm{mg}$ in all studies except one study that applied a dose of $320 \mathrm{mg}$ [19]. Baseline characteristics of included studies are detailed in Table 1.

Five studies used the Child-Pugh score to classify their included participants [12, 18, 19, 21, 22]. Out of 228 patients in the megestrol group, 85 (37.28\%) were classified as Child-Pugh A, 73 (32.01\%) were on Child-Pugh B, and only 21 (9.21\%) participants were assessed as Child-Pugh C. In the control group: 57 (44.18\%) out of 129 were ChildPugh A, 55 (42.63\%) Child-Pugh B, and only 15 (11.62\%) Child-Pugh C. Four trials used the Eastern Cooperative Oncology Group (ECOG) performance score, and most of the patients (282 [93.06\%]) scored 0-2. A detailed description of the Child-Pugh score, ECOG score, and tumour staging are shown in Table 2.

\section{Survival}

Pooling four studies including 87 megestrol-treated patients, the overall mean survival time was $9.187(95 \% \mathrm{Cl}$ 1.134-17.239) months (Fig. 2). Two studies were not eligible for meta-analysis. In the first study, the median survival, in 
Table 1. Baseline characteristics of included studies

\begin{tabular}{|c|c|c|c|c|c|c|c|c|c|c|}
\hline \multirow[t]{2}{*}{ Reference } & \multirow[t]{2}{*}{ Country } & \multirow[t]{2}{*}{$\begin{array}{l}\text { Study } \\
\text { design }\end{array}$} & \multicolumn{2}{|l|}{ Intervention } & \multicolumn{2}{|c|}{ Sample: $n$} & \multicolumn{2}{|c|}{$\begin{array}{c}\text { Age: median (range) } \\
\text { in years }\end{array}$} & \multicolumn{2}{|c|}{ Male: $n(\%)$} \\
\hline & & & Case & Control & Case & Control & Case & Control & Case & Control \\
\hline $\begin{array}{l}\text { Chow et al. } \\
2011[19]\end{array}$ & $\begin{array}{l}\text { Multi- } \\
\text { national }\end{array}$ & $\mathrm{RCT}$ & 320 mg/day MA & Placebo & 123 & 62 & $\begin{array}{c}60.9 \\
(31.1-80.9)\end{array}$ & $\begin{array}{c}56 \\
(20.1-100.3)\end{array}$ & $\begin{array}{c}108 \\
(87.8)\end{array}$ & $\begin{array}{c}51 \\
(82.3)\end{array}$ \\
\hline $\begin{array}{l}\text { Giacomin et al. } \\
2010 \text { [12] }\end{array}$ & Italy & $\mathrm{RCT}$ & 160 mg/day MA & $\begin{array}{l}\text { Synchro- } \\
\text { Levels }\end{array}$ & 18 & 43 & $\begin{array}{c}<65: 0 \\
65-75: 8 \\
>75: 5\end{array}$ & $\begin{array}{c}<65: 5 \\
65-75: 23 \\
>75: 12\end{array}$ & $13(72.2)$ & $30(69.8)$ \\
\hline $\begin{array}{l}\text { Cappa et al. } \\
2005[21]\end{array}$ & Italy & $\begin{array}{l}\text { Clinical } \\
\text { trial }\end{array}$ & $\begin{array}{c}5 \text { cases: } 160 \text { mg/day MA, } \\
\text { 50-300 mg/day } \\
\text { thalidomide; } \\
4 \text { cases: as before, } \\
\text { plus } 1 \text { million U/day IL-2 }\end{array}$ & None & 9 & None & $72(59-81)$ & None & $6(66.6)$ & None \\
\hline $\begin{array}{l}\text { Villa et al. } \\
2001[18]\end{array}$ & Italy & $\mathrm{RCT}$ & 160 mg/day MA & Placebo & 21 & 24 & $63 \pm 8^{*}$ & $60 \pm 11^{\star}$ & $14(67)$ & $22(92)$ \\
\hline $\begin{array}{l}\text { Chao et al. } \\
1997[17]\end{array}$ & Taiwan & $\begin{array}{l}\text { Clinical } \\
\text { trial }\end{array}$ & 160 mg/day MA & None & 46 & None & $65(38-81)$ & None & $44(95.7)$ & None \\
\hline $\begin{array}{l}\text { Colleoni et al. } \\
1995 \text { [22] }\end{array}$ & Italy & $\begin{array}{l}\text { Clinical } \\
\text { trial }\end{array}$ & 160 mg/day MA & None & 11 & None & $68(54-74)$ & None & 9 (81.8) & None \\
\hline
\end{tabular}

Table 2. Clinical scores and tumour staging for included participants

\begin{tabular}{|c|c|c|c|c|c|c|}
\hline \multirow[t]{2}{*}{ Reference } & \multicolumn{2}{|c|}{ Child-Pugh class: $n(\%)$} & \multicolumn{2}{|c|}{ ECOG status: $n(\%)$} & \multicolumn{2}{|c|}{ Tumour staging: $n(\%)$} \\
\hline & Case & Control & Case & Control & Case & Control \\
\hline $\begin{array}{l}\text { Chow et al. } \\
2011[19]\end{array}$ & $\begin{array}{c}\text { A: } 59(48.0) \\
\text { B: } 45(36.6) \\
\text { C: } 16(13.0) \\
\text { unknown: } 3(2.4)\end{array}$ & $\begin{array}{c}\text { A: } 27(43.5) \\
\text { B: } 25(40.3) \\
\text { C: } 8(12.9) \\
\text { unknown: } 2(3.2)\end{array}$ & $\begin{array}{c}0: 12(9.8) \\
1: 69(56.1) \\
2: 30(24.4) \\
3: 12(9.8)\end{array}$ & $\begin{array}{l}0: 14(22.6) \\
1: 33(53.2) \\
2: 13(21.0) \\
3: 2(3.2)\end{array}$ & $\begin{array}{c}\text { TNM staging } \\
\text { II: } 10(8.1) \\
\text { IIIA: } 33(26.8) \\
\text { IIIB: } 6(4.9) \\
\text { IVA: } 41(33.3) \\
\text { IVB: } 17(13.8) \\
\text { Unknown: } 16(13.0)\end{array}$ & $\begin{array}{l}\text { TNM staging } \\
\text { II: } 12(19.4) \\
\text { IIIA: } 16(25.8) \\
\text { IIIB: } 2(3.2) \\
\text { IVA: } 16(25.8) \\
\text { IVB: } 10(16.1) \\
\text { Unknown: } 6(9.7)\end{array}$ \\
\hline $\begin{array}{l}\text { Giacomin et al. } \\
2010 \text { [12] }\end{array}$ & $\begin{array}{l}\text { A: } 8(44.4) \\
B: 10(55.6)\end{array}$ & $\begin{array}{l}A: 20(46.5) \\
B: 23(53.5)\end{array}$ & $\begin{array}{c}0-1: 14(77.7) \\
2: 4(22.2)\end{array}$ & $\begin{array}{c}0-1: 40 \\
(93.0) \\
2: 3(7.0)\end{array}$ & NA & NA \\
\hline $\begin{array}{l}\text { Cappa et al. } \\
2005[21]\end{array}$ & $\begin{array}{l}\text { A: } 3(33.3) \\
\text { B: } 5(55.5) \\
\text { C: } 1(11.1)\end{array}$ & None & NA & None & $\begin{array}{l}\text { CLIP staging } \\
\text { 1: } 1(11.1) \\
\text { 2: } 5(55.5) \\
\text { 3: } 1(11.1) \\
\text { 5: } 1(11.1) \\
6: 1(11.1)\end{array}$ & None \\
\hline $\begin{array}{l}\text { Villa et al. } \\
2001 \text { [18] }\end{array}$ & $\begin{array}{l}A: 11(52.3) \\
B: 6(28.5) \\
C: 4(19.0)\end{array}$ & $\begin{array}{c}\text { A: } 10(41.6) \\
\text { B: } 7(29.1) \\
C: 7(29.1)\end{array}$ & NA & NA & $\begin{array}{c}\text { Histological } \\
\text { differentiation } \\
\text { Well differentiated: } \\
9 \text { (42.9) } \\
\text { Moderate: } 6 \text { (28.6) } \\
\text { Poor: } 4 \text { (19.0) } \\
\text { Unknown: } 2 \text { (9.5) }\end{array}$ & $\begin{array}{c}\text { Histological } \\
\text { differentiation } \\
\text { Well differentiated: } \\
14 \text { (58.3) } \\
\text { Moderate: } 5 \text { (20.8) } \\
\text { Poor: } 2 \text { (8.3) } \\
\text { Unknown: } 3 \text { (12.5) }\end{array}$ \\
\hline $\begin{array}{l}\text { Chao et al. } \\
1997 \text { [17] }\end{array}$ & NA & None & $\begin{array}{c}0-2: 39 \\
(84.8) \\
3-4: 7(15.2)\end{array}$ & None & $\begin{array}{l}\text { AJCC staging } \\
\text { III: } 7(15.2) \\
\text { IV: } 39(84.8)\end{array}$ & None \\
\hline $\begin{array}{l}\text { Colleoni et al. } \\
1995 \text { [22] }\end{array}$ & $\begin{array}{l}A: 4(36.3) \\
B: 7(63.6)\end{array}$ & None & $\begin{array}{l}0-1: 7(63.6) \\
2: 4(36.3)\end{array}$ & None & $\begin{array}{l}\text { TNM staging } \\
\text { III: } 2(18.1) \\
\text { IVA: } 7 \text { (63.6) } \\
\text { IVB: } 2 \text { (18.1) }\end{array}$ & None \\
\hline
\end{tabular}

NA - not applicable; AJCC - American Joint Committee on Cancer; TNM - tumour nodes and metastases; ECOG - Eastern Cooperative Oncology Group 
Statistics for each study

Mean and 95\% C

Standard Variance Lower Upper p-value Total

\begin{tabular}{lccccccc}
\hline & Mean & $\begin{array}{c}\text { Standard Variance } \\
\text { error }\end{array}$ & $\begin{array}{c}\text { Lower } \\
\text { limit }\end{array}$ & $\begin{array}{l}\text { Upper } \\
\text { limit }\end{array}$ & $p$-value & Total \\
\hline Cappa et al. 2005 & 10.25 & 0.514 & 0.264 & 9.243 & 11.257 & 0 & 9 \\
\hline Villa et al. 2001 & 18 & 0.125 & 0.016 & 17.755 & 18.245 & 0 & 21 \\
\hline Chao et al. 1997 & 4 & 0.146 & 0.021 & 3.715 & 4.285 & 0 & 46 \\
\hline Colleoni et al. 1995 & 4.5 & 0.157 & 0.025 & 4.192 & 4.808 & 0 & 11 \\
\hline & 9.187 & 4.109 & 16.881 & 1.134 & 17.239 & 0.025 & 87 \\
\hline
\end{tabular}

Heterogeneity: $1^{2}=99.957 \%, p=0$

Test for overall effect: Mean $=9.187, p=0.025$

$\mathrm{MD}$ - mean difference; $\mathrm{Cl}$ - confidence interval; $p$ - $p$-value

Fig. 2. Forest plot meta-analysis for the overall mean survival of the four included studies

Table 3. Changes in AFP levels in intervention group

\begin{tabular}{|c|c|}
\hline Reference & Changes in AFP \\
\hline Giacomin et al. 2010 [12] & AFP level decreased in $40 \%$ of the megestrol group compared to $14 \%$ in the control group $(p=0.0444)$ \\
\hline Cappa et al. 2005 [21] & AFP progressively increased in six patients while remainingng stable in three \\
\hline Chao et al. 1997 [17] & $\begin{array}{l}\text { AFP level was reduced in five patients with a median reduction of } 59 \mathrm{ng} / \mathrm{ml} \text {. Also, one patient had a reduction } \\
\text { in AFP of } 136,381 \mathrm{ng} / \mathrm{ml} \text { (from } 138,810 \text { to } 2429 \mathrm{ng} / \mathrm{ml} \text { ) }\end{array}$ \\
\hline Colleoni et al. 1995 [22] & No patient had a significant decrease in AFP (> 50\%) \\
\hline
\end{tabular}

Table 4. Adverse events of megestrol versus control group after intervention

\begin{tabular}{|c|c|c|}
\hline Reference & Case: $n(\%)$ & Control: $n(\%)$ \\
\hline Chow et al. 2011 [19] & $\begin{array}{l}\text { Ascites: } 4 \text { (11.4) } \\
\text { Gl bleeding: } 7 \text { (20.0) } \\
\text { Jaundice: } 6 \text { (17.1) } \\
\text { Abdominal pain: } 4 \text { (11.4) } \\
\text { Anaemia: } 3 \text { (8.6) } \\
\text { Tumour rupture: } 1 \text { (2.9) } \\
\text { Pneumonia: } 1 \text { (2.9) } \\
\text { Admitted for limb pain: } 1 \text { (2.9) } \\
\text { Chest pain: } 1 \text { (2.9) } \\
\text { Epistaxis: } 1 \text { (2.9) } \\
\text { Fall: } 1 \text { (2.9) } \\
\text { Hypoglycaemia: } 1 \text { (2.9) }\end{array}$ & $\begin{array}{l}\text { Ascites: } 4 \text { (26.7) } \\
\text { Jaundice: } 1 \text { (6.7) } \\
\text { Abdominal pain: } 1 \text { (6.7) } \\
\text { Anaemia: } 1 \text { (6.7) } \\
\text { Tumour rupture: } 2 \text { (13.3) } \\
\text { Pneumonia: } 1 \text { (6.7) } \\
\text { Admitted for UTI: } 1 \text { (6.7) } \\
\text { Cholangitis: } 1 \text { (6.7) }\end{array}$ \\
\hline Giacomin et al. 2010 [12] & Tolerable itching: 1 (5.5) & None \\
\hline Cappa et al. 2005 [21] & $\begin{array}{l}\text { Increase in appetite and weight: } 7 \text { (77.7) } \\
\text { Peritoneal effusion: } 2 \text { (22.2) } \\
\text { Somnolence: } 9 \text { (100) }\end{array}$ & NA \\
\hline Villa et al. 2001 [18] & $\begin{array}{l}\text { Increase in appetite: } 15 \text { (71.4) } \\
\text { Increase in weight: } 13(61.9) \\
\text { DVT: } 1 \text { (4.1) } \\
\text { Moderate vaginal spotting: } 1 \text { (4.1) }\end{array}$ & DVT: 1 (4.7) \\
\hline Chao et al. 1997 [17] & $\begin{array}{l}\text { Mild congestive cardiac failure: } 1 \text { (2.2) } \\
\text { Hyperglycaemia: } 1(2.2) \\
\text { Mild oedema: } 9 \text { (19.5) }\end{array}$ & NA \\
\hline Colleoni et al. 1995 [22] & $\begin{array}{l}\text { Worsening of concomitant diabetes: } 2 \text { (18.2) } \\
\text { Gastrointestinal bleeding: } 1 \text { (9.1) }\end{array}$ & NA \\
\hline
\end{tabular}

UTI - urinary tract infection; DVT - deep vein thrombosis; NA - not applicable

months, for the megestrol-treated group was 1.88 compared to 2.14 for placebo [19]. In the second trial, four patients survived for 12 months or more after receiving megestrol, compared to one patient on the Synchro-Levels $(p=0.025)$ [12].

\section{Tumour size}

In the study conducted by Cappa et al. five patients had an increase in size/number of nodules, while three patients had tumour enlargement and metastasis [21]. In 
contrast, seven patients had a median tumour size reduction of $18 \%$, and one patient had a reduction of tumour size of $40 \%$ in the Chao et al. trial [17].

\section{Appetite}

In three studies including 76 participants, 42 (55.26\%) patients reported improvement in appetite and food intake after receiving megestrol $[17,18,21]$.

\section{Alpha-fetoprotein}

In the study by Giacomin et al. and Chao et al. there was a significant decrease in alpha-fetoprotein (AFP) levels in the treatment group when compared to the control group. The study by Colleoni et al. showed that no patient had a substantial reduction in AFP (> 50\%). AFP progressively increased in six patients, while it remained stable in three, in the study by Cappa et al. A detailed description of the AFP level is shown in Table 3.

\section{Adverse events}

The reported side effects were generally tolerable in most studies. Gastrointestinal bleeding was reported in studies by Chow et al. and Colleoni et al. [19, 22]. There were no conjoint adverse events between studies except for an increase in weight and appetite in two studies [18, 21]. Itemised characterisation of the reported adverse events are shown in Table 4.

\section{Discussion}

HCC is one of the most common tumours worldwide, and it has a dismal prognosis [1]. Due to the associated comorbidities and the liver resistance to systemic chemotherapy, clinical and experimental studies have been examining the role of hormones in patients with HCC [23, 24]. Megestrol is a synthetic progestin agent, with efficacious anti-oestrogen activity independent of oestrogen receptors. Our systematic review of interventional studies showed that megestrol might play a promising role in prolonging the survival, improving performance, and reducing tumour size. Although in vitro studies on rat livers showed that MA has high resistance to metabolising enzymes compared to progesterone $[25,26]$, there were no serious adverse events detected in most of our included studies.

Administering megestrol for HCC patients may have a favourable outcome at the level of patients' quality of life. For instance, previous systematic review and meta-analysis concluded that megestrol is a safe and efficacious remedy for improving appetite in different categories, including oncology patients [27]. The four included studies supported this effect: two controlled studies illustrated improved appetite in the megestrol-treated group compared to placebo $[18,19]$, whereas two uncontrolled studies reported improvement of appetite and food intake after receiving megestrol [17, 21].

It is evident that megestrol can also improve the performance of HCC patients. In Giacomin et al.'s study, more patients in the megestrol group reported improvement of performance status (ECOG) compared to the control group [12]. In a single arm trial by Chao et al., only four patients had an improvement in their performance status [17]. However, it was noted that most of the patients in the two trials were enrolled at moderate ECOG score (0-2). Also, we noted improvement of performance status in the letter of Farinati et al., in which seven patients (18.9\%) experienced a slight amelioration of their performance status (Karnowski score) [28].

The contrary results of megestrol effects on tumour size are controversial. Eight patients in the Cappa et al. trial [21], had tumour size enlargement versus eight patients who had tumour reduction in the study of Chao et al. 1997 [17]. These diverse results may have been influenced by the varied clinical status of the patients at the time of inclusion. Unfortunately, those studies did not employ the same assessment method of performance to underpin our thinking. The finding of the Chao et al. trial has been established by two excluded letters. In a letter of the case report, the $\mathrm{CT}$ of the patient revealed a significant reduction in tumour bulk from $7 \mathrm{~cm} \times 7.5 \mathrm{~cm}$ to $4.9 \mathrm{~cm} \times 3.3 \mathrm{~cm}$ [29]. In the second part of the non-randomised study of $37 \mathrm{HCC}$ patients, the tumour mass in one patient decreased by more than 50\% [28]. Moreover, when researchers examined the megestrol effect in experimental studies, tumour regression was detected in two out of five included patients [30]. In another pilot study the anti-oestrogen treatment was determined according to the type of liver oestrogen-receptors (ERs) transcript [31]. The patients with wild-type ERs (wtERs) received tamoxifen, while those with variant ER (VERs) received megestrol. Although the sample size was small, all patients on megestrol had considerable slowdown of tumour growth rate [31].

Similar to the study above, the patients of the Villa et al. trial had no tumour size reduction, but the megestrol showed remarkable slow-down of growth [17]. The mean tumour mass at baseline was not significantly different between megestrol and placebo groups; however, the median time to first tumour progression was significantly longer in the megestrol group (22 months) compared to placebo group (nine months) [17].

The present systematic review is the first review to assemble the findings from interventional studies regarding the efficacy and safety of megestrol in patients with inoperable HCC. Another strength of the current review is that we searched five major databases, including Embase and Web of Science. Our study has several limitations. Because of the small number of included studies and absence of decisive inference, health-care professionals should cautiously interpret the results displayed in this systematic review in the clinical settings. Another limitation is the lack of homogeneity between included studies and the measurement of outcomes in diverse methods, which hindered us from carrying out a quantitative meta-analysis. Furthermore, lack of randomisation and controlled arms in half of the included trials may inundate the reliability of their inferences. Researchers should take into consideration these limitations in future studies.

\section{Conclusions}

In summary, the curative effects of megestrol in HCC are controversial; hence, no conclusive evidence can be drawn 
regarding the effectiveness of megestrol in patients with inoperable HCC. However, previous studies have shown promising results at the level of prolonging the survival rate, tumour size reduction, and improving the quality of life. Future trials should consider using megestrol alone or megestrol in addition to chemotherapy in inoperable HCC. Therefore, we recommend that future research studies examine the megestrol role in large-population, randomised studies.

The authors declare no conflict of interest.

\section{References}

1. Parkin DM. Global cancer statistics. CA Cancer J Clin 2005; 55: 74108.

2. Hepatocellular carcinoma - United States, 2001-2006. MMWR Morb Mortal Wkly Rep 2010; 59: 517-520.

3. Bray F, Ferlay J, Soerjomataram I, Siegel RL, Torre LA, Jemal A. Global cancer statistics 2018: GLOBOCAN estimates of incidence and mortality worldwide for 36 cancers in 185 countries. CA Cancer J Clin 2018; 68: 394-424.

4. Ferlay J, Shin HR, Bray F, Forman D, Mathers C, Parkin DM. Estimates of worldwide burden of cancer in 2008: GLOBOCAN 2008. Int J Cancer 2010; 127: 2893-2917.

5. El-Serag HB. Hepatocellular carcinoma: recent trends in the Unit ed States. Gastroenterology 2004; 127: S27-34.

6. Crissien AM, Frenette C. Current management of hepatocellular carcinoma. Gastroenterol Hepatol (N Y) 2014; 10: 153-161.

7. Llovet JM, Burroughs A, Bruix J. Hepatocellular carcinoma. Lancet 2003; 362: 1907-1917.

8. Llovet JM, Bruix J. Systematic review of randomized trials for unresectable hepatocellular carcinoma: Chemoembolization improves survival. Hepatology 2003; 37: 429-442.

9. Llovet JM, Ducreux M, Lencioni R, et al. European Association for the Study of the Liver European Organisation for Research and Treatment of Cancer: EASL-EORTC clinical practice guidelines: management of hepatocellular carcinoma. J Hepatol 2012; 56: 908-943.

10. Bruix J, Sherman M. Management of hepatocellular carcinoma: an update. Hepatology 2011; 53: 1020-1022.

11. Federico A, Orditura M, Cotticelli G, et al. Safety and efficacy of sorafenib in patients with advanced hepatocellular carcinoma and Child-Pugh A or B cirrhosis. Oncol Lett 2015; 9: 1628-1632.

12. Giacomin AS, Sergio A, Vanin V, Tartaro P, Paccagnella D, Mazzucco M, Farinati F. Megestrol and embryonic extracts in the treatment of advanced hepatocellular carcinoma: A prospective randomized trial in the pre-sorafenib era. Hepatol Res 2010; 40: 153-160.

13. Nowak A, Findlay M, Culjak G, Stockler M. Tamoxifen for hepatocellular carcinoma. Cochrane Database Syst Rev 2004; Cd001024.

14. Villa ED, Dugani A, Fantoni E, et al. Type of estrogen receptor determines response to antiestrogen therapy. Cancer Res 1996; 56: 3883-3885.

15. Liu C-L, Fan S-T, Ng O-L, et al. Treatment of advanced hepatocellular carcinoma with tamoxifen and the correlation with expression of hormone receptors: a prospective randomized study. Am J Gastroenterol 2000; 95: 218.

16. Zhang KC, Chow PK. The effect of megestrol acetate on growth of HepG2 cells in vitro and in vivo. Clin Cancer Res 2004; 10: 52265232

17. Chao YC, Chan WK, Wang SS, et al. Phase II study of megestrol acetate in the treatment of hepatocellular carcinoma. J Gastroenterol Hepatol 1997; 12: 277-281.

18. Villa EF, Ferretti I, Grottola A, et al. Hormonal therapy with megestrol in inoperable hepatocellular carcinoma characterized by variant oestrogen receptors. Br J Cancer 2001; 84: 881-885.
19. Chow PK, Machin D, Chen Y, et al. Randomised double-blind trial of megestrol acetate vs placebo in treatment-naive advanced hepatocellular carcinoma. Br J Cancer 2011; 105: 945-952.

20. Hozo SP, Djulbegovic B, Hozo I. Estimating the mean and variance from the median, range, and the size of a sample. BMC Med Res Methodol 2005; 5: 13.

21. Cappa FM, Cantarini MC, Magini G, et al. Effects of the combined treatment with thalidomide, megestrol and interleukin-2 in cirrhotic patients with advanced hepatocellular carcinoma. Dig Liver Dis 2005; 37: 254-259.

22. Colleoni M, Nelli P, Vicario G, Mastropasqua G, Manente P. Megestrol acetate in unresectable hepatocellular carcinoma. Tumori 1995; 81: 351-353.

23. Abou-Alfa GK. Hepatocellular carcinoma: molecular biology and therapy. Semin Oncol 2006; 33: S79-83.

24. Di Maio MD, Daniele B, Pignata S, et al. Is human hepatocellular carcinoma a hormone-responsive tumor? World I Gastroenterol 2008; 14: 1682-1689.

25. David A, Edwards K, Fellowes K, Plummer J. Anti-ovulatory and other biological properties of megestrol acetate 17 aacetoxy- 6 methyl pregna 4: 6-diene-3: 20-dione (BDH 1298). J Reprod Fertil 1963; 5 : 331-346.

26. Cooke BA, Vallance DK. Metabolism of megestrol acetate and related progesterone analogues by liver preparations in vitro. Biochem J 1965; 97: 672-677.

27. Pascual López A, Roqué i Figuls M, Urrútia Cuchi G, Berenstein EG, Almenar Pasies B, Balcells Alegre M, Herdman M. Systematic review of megestrol acetate in the treatment of anorexia-cachexia syndrome. J Pain Symptom Manage 2004; 27: 360-369.

28. Farinati FG, Gianni S, De Giorgio M, Fiorentini, S. Megestrol treatment in patients with hepatocellular carcinoma. Br J Cancer 2001; 85: 1606-1607.

29. Ouek RS, Thye Lim S, Ong S. Hepatocellular carcinoma - Pathological complete response to oral capecitabine, megestrol and thalidomide. Acta Oncol 2006; 45: 95-97.

30. Friedman MA, Demanes DJ, Hoffman PG Jr. Hepatomas: Hormone receptors and therapy. Am J Med 1982; 73: 362-366.

31. Villa E, Dugani A, Fantoni E, et al. Type of estrogen receptor determines response to antiestrogen therapy. Cancer Res 1996; 56: 3883-3885.

\section{Address for correspondence}

\section{Prashanth Rawla}

Sovah Health - Martinsville

320 Hospital Drive

Martinsville, VA 24115

United States

e-mail: rawlap@gmail.com

Submitted: 13.09 .2018

Accepted: 24.09 .2018 